
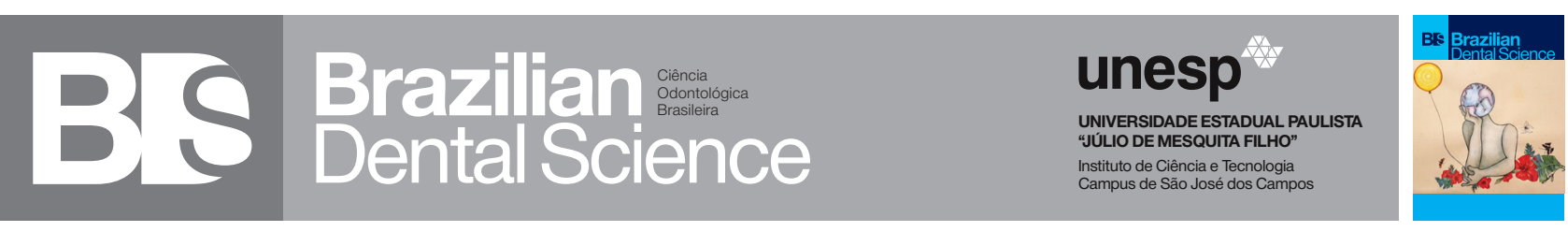

\title{
Initial and pulp chamber concentration of hydrogen peroxide using different bleaching products
}

\author{
Concentração de peróxido de hidrogênio na câmara pulpar utilizando diferentes produtos clareadores
}

\begin{abstract}
Sibelli Olivieri PARREIRAS ${ }^{1}$, Michael Willian FAVORETO' ${ }^{1}$, Gustavo Pereira CRUZ $^{1}$, Anderson GOMES ${ }^{2}$, Christiane Philippini Ferreira BORGES $^{2}$, Alessandro D. LOGUERCIO ${ }^{1}$, Alessandra REIS ${ }^{1}$

1 - Department of Restorative Dentistry. State University of Ponta Grossa - Ponta Grossa - PR - Brazil.

2 - Department of Apllied Chemistry. State University of Ponta Grossa - PR - Ponta Grossa - Brazil.
\end{abstract}

\begin{abstract}
Objective: This study's aim was to quantify the hydrogen peroxide (HP) penetration into the pulp chamber of teeth submitted to different protocols of bleaching. Material and Methods: Ninety premolars were randomly divided into nine groups according to the bleaching agent protocol ( $\mathrm{n}=10)$ : control (no bleaching), carbamide peroxide $10 \%$ [10\% CP], carbamide peroxide $16 \%$ [16\% $\mathrm{CP}$ ], carbamide peroxide $22 \%$ [22\% CP], hydrogen peroxide $4 \%[4 \% \mathrm{HP}]$, hydrogen peroxide $6 \%[6 \%$ HP], hydrogen peroxide 7.5\% [7.5\% HP], hydrogen peroxide $10 \%[10 \% \mathrm{HP}]$ and hydrogen peroxide $35 \%$ [35\% HP]. The penetration of HP was measured via spectrophotometric analysis of the acetate buffer solution from the pulp chamber. The absorbance of the resulting solution was determined in a spectrophotometer and converted into equivalent concentration of HP ( $\mu \mathrm{g} /$ $\mathrm{mL}$ ). To analyze the concentration of HP, the titration of bleaching agents with potassium permanganate was used. Data were subjected to ANOVA and Tukey's test for pairwise comparison $(\alpha=0.05)$. Results: Higher concentration of HP in the pulp chamber was found in the HP 35\% group ( $<<0.0001$ ). No significant difference between at-home protocols were observed ( $\mathrm{p}$ $=0.64$ ). Titration values showed that the concentration of the products was similar to that claimed by the manufacturer. Conclusion: It follows that the amount of HP that reaches the pulp chamber is not proportional to the concentration of whitening gels, but depends on the application time recommended by the manufacturers.
\end{abstract}

\section{KEYWORDS}

At-home bleaching; Dental enamel permeability; Inoffice bleaching; Tooth bleaching.

\section{RESUIMO}

Objetivo: o objetivo deste estudo foi quantificar a penetração do peróxido de hidrogênio $(\mathrm{PH})$ na câmara pulpar dos dentes submetidos a diferentes protocolos de clareamento. Material e Métodos: Noventa pré-molares foram divididos aleatoriamente em nove grupos, de acordo com o protocolo do agente clareador $(n=10)$ : controle (sem clareamento), peróxido de carbamida 10\% [PC 10\%], peróxido de carbamida 16\% [PC 16\%], peróxido de carbamida $22 \%$ [PC 22\%], peróxido de hidrogênio 4\% [PH 4\%], peróxido de hidrogênio 6\% [PH 6\%], peróxido de hidrogênio 7,5\% [PH 7,5\%], peróxido de hidrogênio 10\% [PH 10\%] e peróxido de hidrogênio 35\% [PH 35\%]. A penetração de PH foi medida por análise espectrofotométrica da solução de tampão de acetato da câmara pulpar. A absorvância da solução resultante foi determinada em um espectrofotômetro e convertida em concentração equivalente de $\mathrm{PH}(\mu \mathrm{g} / \mathrm{mL})$. Para analisar a concentração de $\mathrm{PH}$, foi utilizada a titulação de agentes clareadores com permanganato de potássio. Os dados foram submetidos à ANOVA e teste de Tukey para comparação pareada $(\alpha=0,05)$. Resultados: Foi encontrada maior concentração de $\mathrm{PH}$ na câmara pulpar no grupo PH 35\% (p < 0,0001). Não foi observada diferença significativa entre os protocolos domiciliares $(p=0,64)$. Os valores de titulação mostraram que a concentração dos produtos era semelhante à reivindicada pelo fabricante. Conclusão: Conclui-se que a quantidade de $\mathrm{PH}$ que atinge a câmara pulpar não é proporcional à concentração de géis clareadores, porém depende do tempo de aplicação recomendado pelos fabricantes.

\section{PALAVRAS-CHAVE}

Clareamento dental; Permeabilidade de esmalte dentário; Clareadores; Peróxido de hidrogênio; Peróxido de carbamida. 


\section{INTRODUCTION}

$\mathrm{T}$ he demand for dental bleaching products has increased significantly over the past year. In some countries, $85.9 \%$ of the surveyed adult population have the desire to perform tooth bleaching [1]. Hydrogen peroxide and carbamide peroxide are the most common dentist-supervised products used in dental clinics for bleaching [2]. For at-home bleaching, the products employed different concentrations of carbamide peroxide (5\% to $22 \%$ ) or hydrogen peroxide ranging from $3 \%$ to $10 \%$. On the other hand, in-office bleaching employs highly concentrated hydrogen peroxide gels - typically in the range of 20 to $38 \%$ [3-5].

All these bleaching products have shown effective color changes both at the immediate and in middle-term follow-ups [6,7]. However, more than $50 \%$ of the patients submitted to at-home and in-office bleaching experience bleaching-induced tooth sensitivity. The risk and severity of tooth sensitivity depends on: 1 ) the bleaching technique [8,9], which are directly related to the hydrogen peroxide concentration and usage time [10-12] and 2) patient-related factors, such as baseline tooth color and age [8]. Unfortunatelly, cell viability reduction, $\mathrm{H}_{2} \mathrm{O}_{2}$ diffusion, cell morphology alteration, oxidative stress, and cell membrane damage of pulp cells depend on the concentration of hydrogen peroxide and contact time of this products $[13,14]$

In regard to the bleaching technique, Rezende et al. (2016) [8] reported that athome bleaching protocols have lower tooth sensitivity than in-office bleaching. In a 0 to 4 pain scale, the mean tooth sensitivity of at-home bleaching was $0.5 \pm 0.9$, while inoffice bleaching was $2.8 \pm 2.9$. Perhaps, such differences may be related to the amount of hydrogen peroxide that reaches the pulp chamber. Hydrogen peroxide from carbamide peroxide products, for instance, appears to penetrate less than the hydrogen peroxide of equivalent concentration [15]. Tooth exposure with $15 \%$ carbamide peroxide gel (equivalent to $5.3 \%$ hydrogen peroxide) resulted in a mean pulp chamber concentration of peroxide that was less than half caused by exposure to pure $5 \%$ hydrogen peroxide [15].

The penetration of hydrogen peroxide within the dental structures, that occurs in only 15 minutes [16], seems to be dose dependent [16]. In a clinical study using similar protocols, a higher risk of tooth sensitivity was experienced by the patients who used the 20\% CP (71.4\%) than the ones who used 10\% CP (36.8\%) [10]. Variations in the amount of the hydrogen peroxide that reaches the pulp chamber using different bleaching protocols are of clinical interest such it may allow clinicians to choose the best protocol for highly sensitive patients. In face of that the aim of this study was to quantify and correlate the initial amount of hydrogen peroxide of bleaching products with the amount of hydrogen peroxide that reaches the pulp chamber using different bleaching protocols.

\section{MATERIAL AND METHODS}

The local Ethics Committee from the University approved this study under protocol number 1.614.755. A total of ninety sound premolars without fractures and enamel defects were randomly divided by lottery into nine groups according to dental bleaching system to be used: 1) control (distilled water) 2) carbamide peroxide $10 \%$ (10\% $\mathrm{CP})$; 3) carbamide peroxide 16\% (16\% CP); 4) carbamide peroxide $22 \%(22 \% \mathrm{CP}) ; 5)$ hydrogen peroxide $4 \%$ (4\% HP); 6) hydrogen peroxide $6 \%$ (6\% HP); 7) hydrogen peroxide $7.5 \%(7.5 \% \mathrm{HP}) ; 8)$ hydrogen peroxide $10 \%$ (10\% HP); 9) hydrogen peroxide 35\% (35\% HP). All dental bleaching systems used in the present study are from the same company (FGM Dental products, Joinville, SC, Brazil) and their composition and mode of use are described in the Table I. Ten teeth were used in each group. 
Table I - Batch number, composition and mode of application of the products used in this study

\begin{tabular}{|c|c|c|c|}
\hline Groups & Main components & $\begin{array}{l}\text { Batch } \\
\text { number }\end{array}$ & $\begin{array}{l}\text { Mode of } \\
\text { application }\end{array}$ \\
\hline $\begin{array}{l}\text { 10\% Carbamide } \\
\text { Peroxide }\end{array}$ & $\begin{array}{l}10 \% \text { Carbamide Peroxide, Neutralized } \\
\text { Carbopol, Potassium Nitrate, Sodium } \\
\text { Fluoride, Humectant (Glycol), Deionized } \\
\text { Water. }\end{array}$ & $\begin{array}{c}02.04 .14 \\
21.09 .2016\end{array}$ & 3 hours a day \\
\hline $\begin{array}{l}\text { 16\% Carbamide } \\
\text { Peroxide }\end{array}$ & $\begin{array}{l}16 \% \text { Carbamide Peroxide, Neutralized } \\
\text { Carbopol, Potassium Nitrate, Sodium } \\
\text { Fluoride, Humectant (Glycol),Deionized } \\
\text { Water. }\end{array}$ & $\begin{array}{l}18.08 .2016 \\
19.10 .2016\end{array}$ & 3 hours a day \\
\hline $\begin{array}{l}\text { 22\% Carbamide } \\
\text { Peroxide }\end{array}$ & $\begin{array}{l}\text { 22\% Carbamide Peroxide, Neutralized } \\
\text { Carbopol, Potassium Nitrate, Sodium } \\
\text { Fluoride, Humectant (Glycol),Deionized } \\
\text { Water. }\end{array}$ & $\begin{array}{c}12.11 .2014 \\
03.10 .2016\end{array}$ & 1hour a day \\
\hline $\begin{array}{l}\text { 4\% Hydrogen } \\
\text { Peroxide }\end{array}$ & $\begin{array}{l}\text { Available in 4\% hydrogen peroxide gel. } \\
\text { Neutralized carbopol, potassium nitrate, } \\
\text { sodium fluoride, calcium gluconate, sta- } \\
\text { bilizer, deionized water and surfactant. }\end{array}$ & $\begin{array}{c}13.11 .2013 \\
26.07 .2016\end{array}$ & 2 hour a day \\
\hline $\begin{array}{l}\text { 6\%Hydrogen } \\
\text { Peroxide }\end{array}$ & $\begin{array}{l}\text { Available in 6\% hydrogen peroxide gel. } \\
\text { Neutralized carbopol, potassium nitrate, } \\
\text { sodium fluoride, calcium gluconate, } \\
\text { stabilizer, deionized water and sur } \\
\text { factant. }\end{array}$ & $\begin{array}{l}25.09 .2014 \\
25.09 .2014\end{array}$ & $\begin{array}{l}1 \mathrm{~h} 30 \mathrm{~min} \\
\text { a day }\end{array}$ \\
\hline $\begin{array}{l}\text { 7,5\% Hydrogen } \\
\text { Peroxide }\end{array}$ & $\begin{array}{l}\text { Available in } 71 / 2 \% \text { hydrogen peroxide } \\
\text { gel. Neutralized carbopol, potassium } \\
\text { nitrate, sodium fluoride, calcium glu- } \\
\text { conate, stabilizer, deionized water and } \\
\text { sur factant. }\end{array}$ & $\begin{array}{c}10.12 .2014 \\
26.09 .2016\end{array}$ & 1hour a day \\
\hline $\begin{array}{l}10 \% \text { Hydrogen } \\
\text { Peroxide: }\end{array}$ & $\begin{array}{l}\text { Available in } 10 \% \text { hydrogen peroxide gel. } \\
\text { Neutralized carbopol, potassium nitrate, } \\
\text { sodium fluoride, calcium gluconate, } \\
\text { stabilizer, deionized water and sur } \\
\text { factant. }\end{array}$ & $\begin{array}{l}23.06 .2015 \\
29.09 .2016\end{array}$ & 30 min a day \\
\hline $\begin{array}{l}35 \% \text { Hydrogen } \\
\text { Peroxide }\end{array}$ & $\begin{array}{l}\text { hydrogen peroxide at } 30 \% \text { - } 35 \% \text {, thi- } \\
\text { ckeners, dye mixture, glycol, inorganic } \\
\text { load and deionized water. }\end{array}$ & $\begin{array}{l}26.05 .2014 \\
02.08 .2016\end{array}$ & $\begin{array}{l}\text { Three sessions } \\
\text { of } 15 \text { min each }\end{array}$ \\
\hline
\end{tabular}

* Whiteness Perfect 10\% (10\% CP); Whiteness Perfect 16\% (16\% CP); Whiteness Perfect 22\% (22\% CP); Whiteness Class 4\% (4\% HP); Whiteness Class 6\% (6\% HP); Whiteness Class 7,5\%: (7,5\% HP); Whiteness Class 10\% (10\% HP); Whiteness HPMaxx (35\% $\mathrm{HP})$

* all products used in this study are the same manufacturer's (FGM Dental Products, Joinville, SC, Brazil)

Quantification of the hydrogen peroxide concentration in the pulp chamber

The roots of all teeth were cut approximately $3 \mathrm{~mm}$ apical to the cementoenamel junction. The entrance to the pulp cavities was widened carefully, with a round bur (\#1014, KG Sorensen, Barueri, SP, Brazil) to allow the introduction of a micropipette (LABMATE Soft, HTL Lab Solutions, Warsaw, Poland) inside the pulp chamber. This procedure was done carefully to not touch the internal walls of the pulp chamber. The pulp tissue was removed, and pulp chamber washed with distilled water.
Throughout this study, analytical-grade chemicals without previous purification were used; they were prepared with deionized water from a Millipore Milli-Q system (MS2000, Gehaka, São Paulo, SP, Brazil). Hydrogen peroxide was purchased from LABSYNTH (LABSYNTH, Diadema, SP, Brazil) (34\%- 36\%). A $5000 \mu \mathrm{g} / \mathrm{mL}$ stock solution was prepared in acetate buffer solution $(\mathrm{pH}=4)$ and standardized by conventional methods. The solution was titrated with potassium permanganate standard solution [17]. Aliquots of the stock solution of HP were diluted volumetrically to obtain working standard solutions of $0.032-0.397 \mu \mathrm{g} / \mathrm{mL}$ [18] (Figure 1).

The occlusal surface of all teeth was fixed vertically to a wax plaque and the labial surface area of each tooth where the bleaching agent were applied was isolated by applying a light-cured resin dam (KG Sorensen, Barueri, SP, Brazil). A $25 \mu \mathrm{L}$ aliquot of acetate buffer (pH 4.5) was placed into the pulp chamber of each tooth to absorb and stabilize any peroxide that might penetrate into the pulp chamber.

The bleaching gels were applied over the enamel surface according to the manufacturers' recommendations (Table I) to reproduce the clinical condition. A single-day session was performed for each material (Table I). After the exposure period (Table I), the acetate buffer solution in the pulp chamber of each tooth were removed by means of a mechanical micropipette and transferred to a glass tube. This procedure was done by rinsing the pulp chamber of each tooth four times with 25 $\mu \mathrm{L}$ of acetate buffer, and transferring this solution to the same glass tube. Next, more deionized water $(2.725 \mu \mathrm{L})$ was added to the glass tube along with $100 \mu \mathrm{L}$ of $0.5 \mathrm{mg} / \mathrm{mL}$ of leucocrystal violet (Sigma Chemical Co, St Louis, MO, USA) and $50 \mu \mathrm{L}$ of $1 \mathrm{mg} / \mathrm{mL}$ enzyme horseradish peroxidase (Peroxidase Type VI-A, Sigma Chemical Co, St Louis, MO, USA). This procedure was repeated separately for each tooth.

The absorbance at $596 \mathrm{~nm}$ of the resultant violet color in the tubes was measured in a Cary 50 UV-Vis spectrophotometer (Varian, Palo Alto, CA, USA). According to Beer's Law, absorbance is directly proportional to the 
concentration. Therefore, the concentration of hydrogen peroxide $(\mu \mathrm{g} / \mathrm{mL})$ was determined by comparing it to the calibration curve previously obtained (Figure 1). By knowing the concentration $(\mu \mathrm{g} / \mathrm{mL})$ and volume of the solution, the hydrogen peroxide mass $(\mu \mathrm{g})$ can be calculated [18].

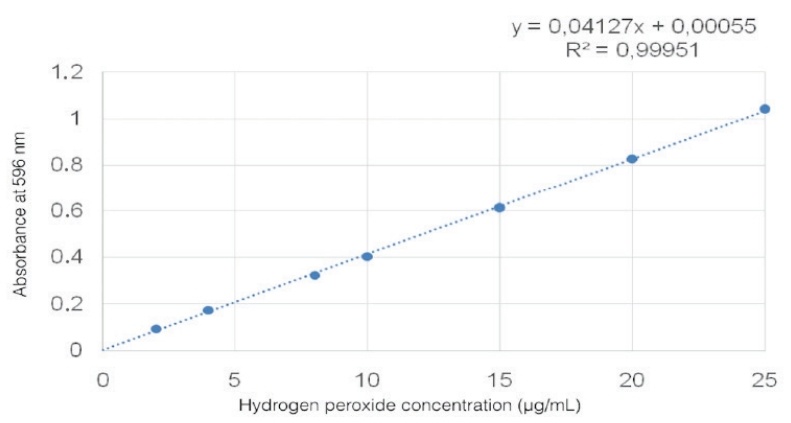

Figure 1 - Spectrophotometric calibration curve used in this study, $R=0.99951$.

Quantification of the initial hydrogen peroxide concentration in the bleaching products

Potassium permanganate was used as an oxidizing agent to describe the initial concentration of hydrogen peroxide in each bleaching product. Hydrogen peroxide reduces the permanganate to a colorless product based on a reduction-oxidation reaction, according to the following formula $[17,19]$ :

$$
\begin{aligned}
& 2 \mathrm{KMnO}_{4}+5 \mathrm{H}_{2} \mathrm{O}_{2}+3 \mathrm{H}_{2} \mathrm{SO}_{4} \rightarrow 1 \mathrm{~K}_{2} \mathrm{SO}_{4} \\
& +2 \mathrm{MnSO}_{4}+5 \mathrm{O}_{2}+8 \mathrm{H}_{2} \mathrm{O}
\end{aligned}
$$

The bleaching agents, whenever required, were mixed in accordance with manufacturers' instructions and were analytically weighted. A sample of bleaching product (approximately $0.2 \mathrm{~g}$ ) was collected and diluted in $50 \mathrm{~mL}$ of distilled water and $10 \mathrm{~mL}$ of 1 mol. $\mathrm{L}^{-1}$ sulfuric acid. Then, the potassium permanganate solution (0.06 mol. $\mathrm{L}^{-1}$ ) was added to this solution $[17,19]$, resulting in a violet color solution. This color change indicated the equivalence point, i.e., the moment when all of the $\mathrm{H}_{2} \mathrm{O}_{2}$ have been consumed. Three titrations for each bleaching gel system were performed.

The hydrogen peroxide mean concentration was calculated by the following formula:

$$
\left.\% \mathrm{H}_{2} \mathrm{O}_{2} \text { (by weight }\right)=\frac{\left(\left(\left(\left(\left(\left(\mathrm{KMnO}_{4} \cdot C_{\mathrm{KMnO}_{4}}\right) / 1000\right) \cdot 5\right) / 2\right) \cdot 34\right) \cdot 100\right)}{m_{\mathrm{H}_{2} \mathrm{O}_{2}\left(\text { grams of } \mathrm{H}_{2} \mathrm{O}_{2} \text { of the sample used }\right)}}
$$

We also calculated the theoretical availability of hydrogen peroxide during each application session by multiplying the titrated concentration of the product ( $\%$ HP) by the number of hours a day recommended by manufacturers.

\section{Statistical analysis}

The data related to the concentration of hydrogen peroxide that reached the pulp chamber were subjected to one-way analysis of variance (ANOVA) and Tukey's tests for pairwise comparisons (alpha $=0.05$ ). The Pearson correlation between the means of the hydrogen peroxide concentration that reached the pulp and the initial hydrogen peroxide concentration in each product was calculated.

\section{RESULTS}

Different amounts of hydrogen peroxide were found in the pulp chamber of the different bleaching protocols (Table II). The amount of hydrogen peroxide from the 35\% HP group was significantly higher than all athome protocols evaluated $(\mathrm{p}<0.0001)$. No statistically significant differences between athome protocols were observed $(\mathrm{p}=0.649)$.

Table II - Means and standard deviations of the HP concentration $(\mu \mathrm{g} / \mathrm{mL})$ detected inside the pulp chamber and concentration of HP found in the commercial products along with the theoretical availability of HP

\begin{tabular}{|ccccc|} 
Bleaching gel & $\begin{array}{c}\text { Concentration } \\
\text { given by the } \\
\text { manufacturer }\end{array}$ & $\begin{array}{c}\text { HP concentra- } \\
\text { tion } \\
(\mu \mathrm{g} / \mathrm{mL})\end{array}$ & $\begin{array}{c}\text { Concentra- } \\
\text { tion of } \mathrm{HP} \\
\text { found in } \\
\text { the product }\end{array}$ & $\begin{array}{c}\text { Theoretical } \\
\text { availability } \\
\text { of HP(\%) }\end{array}$ \\
\hline $\begin{array}{c}\text { Negative } \\
\text { control }\end{array}$ & - & $0.0010 \pm 0.0013 \mathrm{a}$ & - & - \\
\hline Perfect 10\% & $10 \% \mathrm{CP}$ & $0.0138 \pm 0.0094 \mathrm{a}$ & $3.9 \%$ & 11.7 \\
\hline Perfect 16\% & $16 \% \mathrm{CP}$ & $0.0508 \pm 0.0379 \mathrm{a}$ & $6.6 \%$ & 19.8 \\
\hline Perfect 22\% & $22 \% \mathrm{CP}$ & $0.0379 \pm 0.0292 \mathrm{a}$ & $9.0 \%$ & 9.0 \\
\hline Class 4\% & $4 \% \mathrm{HP}$ & $0.0170 \pm 0.0076 \mathrm{a}$ & $4.4 \%$ & 8.8 \\
\hline Class 6\% & $6 \% \mathrm{HP}$ & $0.0327 \pm 0.0252 \mathrm{a}$ & $5.2 \%$ & 7.8 \\
\hline Class 7,5\% & $7,5 \% \mathrm{HP}$ & $0.0308 \pm 0.0138 \mathrm{a}$ & $8.0 \%$ & 7.9 \\
\hline Class 10\% & $10 \% \mathrm{HP}$ & $0.0318 \pm 0.0238 \mathrm{a}$ & $10.2 \%$ & 5.0 \\
\hline HP Maxxx 35\% & $35 \% \mathrm{HP}$ & $0.2800 \pm 0.1412 \mathrm{~b}$ & $31.0 \%$ & 23.2 \\
\hline
\end{tabular}

$\left.{ }^{(*}\right)$ Identical lowercase letters indicate statistically similar means (One-way ANOVA and Tukey's test, $\alpha=0.05$ ). 
The HP concentrations claimed by the manufacturer and the values obtained from permanganate potassium titration are shown in Table II. Titration values showed that the concentration of the products was similar to that claimed by the manufacturer.

A strong and positive correlation $(\mathrm{r}=$ $0.98 ; p=0.0026$ ) was found between the titrated concentration of all products and the concentration of peroxide in the pulp chamber (Figure 4). However, when the same correlation was run only for titrated concentration of the at-home products (excluding the in-office bleaching product), a non-significant correlation was observed ( $\mathrm{r}$ $=0.52 ; \mathrm{p}=0.22$; Figure 2). The theoretical availability of peroxide per application time varied per product and it was not proportional to the concentration of the hydrogen peroxide of the products.

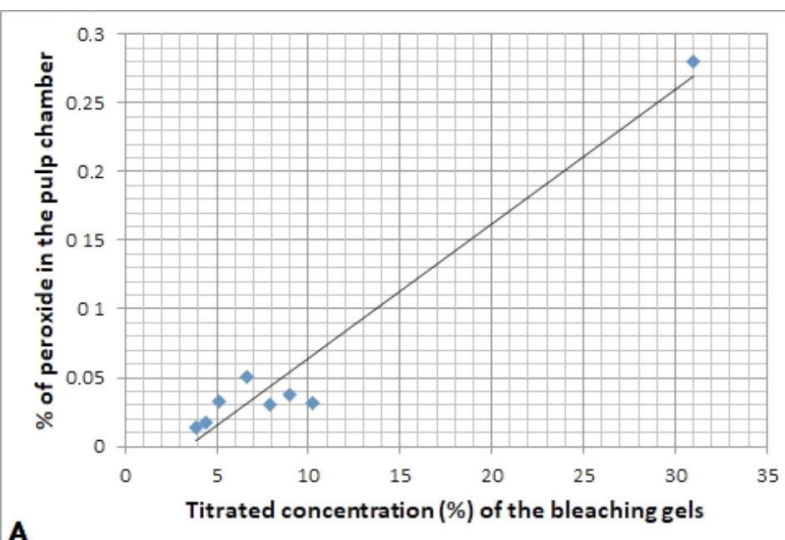

A

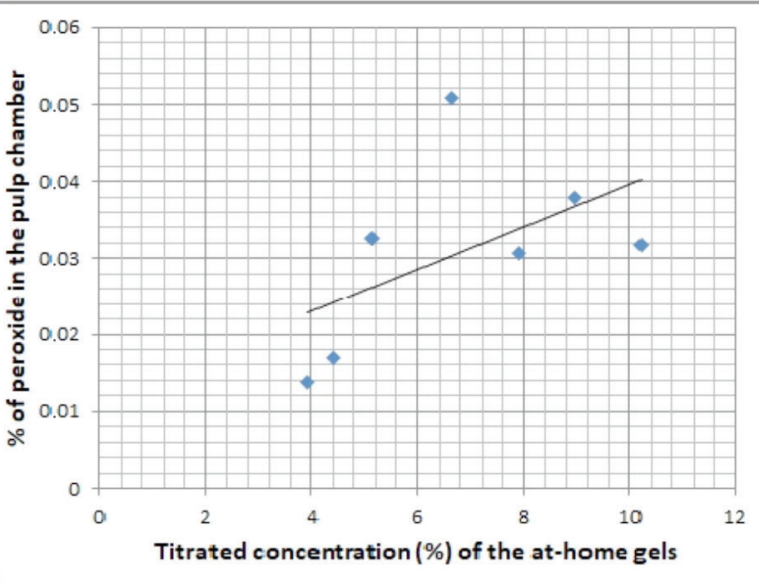

Figure 2 - Correlation of concentration of peroxide in the pulp chamber for all products (A) and only for the and at-home tooth bleaching agents (B).

\section{DISCUSSION}

In the present study, a higher penetration of hydrogen peroxide in extracted human teeth were observed for the in-office tooth bleaching product than any of at-home bleaching agents. These results are in agreement with several previous studies that demonstrated that significant higher amounts of hydrogen peroxide can diffuse through dentin with inoffice protocols [15,16,20]. Additionally, some authors report that higher concentrate hydrogen peroxide products create micropores on enamel surface, which affects the enamel inner structure and enamel surface and may further make easy the passage of hydrogen peroxide through enamel [21].

In the present study, the concentration of hydrogen peroxide found in the pulp chamber for $35 \%$ HP group was higher than other published studies [18,22,23]. Amounts of HP ranging from 1.22 to $6.22 \mu \mathrm{g}$ was observed in the pulp chamber of teeth bleached with $35 \%$ hydrogen peroxide in other studies [18,22,23], while in the present study an average of 28.5 $\mu \mathrm{g}$ was detected for 35\% HP group. These differences may be attributed to variations in the experimental design such as the type of dental substrate used (human or bovine), composition of the gels, experimental protocol, hydrogen peroxide delivery method and differences of cavity preparation. However, this does not reduce the internal validity of all studies as the same conditions were applied for the different treatments within each one of these studies.

In regard to at-home bleaching protocols, the amount of hydrogen peroxide that reached the pulp chamber was similar for all groups. This was expected for products that have the same amount of active hydrogen peroxide. For instance, $10 \%$ carbamide peroxide gel, yields a maximum of $3.5 \%$ hydrogen peroxide, and therefore we anticipated the similar hydrogen peroxide diffusion of $10 \%$ carbamide peroxide and $4 \%$ hydrogen peroxide. The same phenomenon was observed to $22 \%$ carbamide peroxide and $10 \%$ hydrogen peroxide, which presents similar concentrations of active hydrogen peroxide.

However, the non-significant differences between systems with different initial hydrogen 
peroxide concentration was, at first glance, surprising, as previous studies suggested that the amount of hydrogen peroxide that penetrates the dental structure is influenced by its original concentration in the bleaching agent $[15,16,20]$. But this was also observed in several clinical trials.

For instance, a clinical comparison between $10 \%, 15 \%$ and $17 \%$ carbamide peroxide showed statistically similar whitening results [24-27]. Likewise, a similar whitening degree was observed when lower concentrations of hydrogen peroxide was compared with $20 \%$ carbamide peroxide [28-30]. In regard to tooth sensitivity, some authors affirm that $16 \%$ carbamide peroxide provokes more sensitivity than does $10 \%$ carbamide peroxide [24,25], whereas in other studies, there were no significant differences between these concentrations [3,30].

In all clinical studies cited above, the products were employed according to the manufacturer's instructions, and this may be the key for understanding why similar hydrogen peroxide concentrations was observed for at-home products. In the present study, we also followed the manufacturer's recommendations of all products in a way to simulate the clinical condition, as we wanted to compare bleaching protocols rather than bleaching product concentrations.

Bleaching protocols vary in the mode and duration of product application. Products with low active hydrogen peroxide were applied for longer periods of times than highly concentrated products. Therefore, the low concentration of hydrogen peroxide might have been compensated for the longer exposure time on the enamel surface (Table I). This means that not only concentration, but also application time is responsible for the amount of product that reaches the pulp chamber. This explains the lack of correlation between initial hydrogen peroxide concentration and the percentage of hydrogen peroxide that reached the pulp chamber for at-home bleaching products. Had the products been used for the same time, which is not representative of a clinical condition, a significant correlation might have been observed.
This correlation was, however, significant only when the $35 \%$ hydrogen peroxide; the product with the highest hydrogen peroxide concentration, was included in the data. The titrated concentration of hydrogen peroxide multiplied by the usage time (hour), according as manufacturers recommendations, give us the theoretical availability of the product on the enamel surface. This relation was highest for the $35 \%$ hydrogen peroxide product (23\% per application session) in comparison with all other at-home products, which ranged from 5 to $19 \%$ per application session). The only product that showed a different behavior was $16 \%$ carbamide peroxide and deserves further investigations. It is worth pointing out that we have tested two material lots of $16 \%$ carbamide peroxide in the present study to confirm the results herein presented.

Another influential factor of hydrogen peroxide diffusion is the composition of the bleaching gel. The at-home groups present in their composition potassium nitrate and sodium fluoride. The sodium fluoride can form a calcium fluoride layer on the enamel surface which inhibits demineralization [31], which may contribute to a reduced penetration of hydrogen peroxide. Additionally, the at-home hydrogen peroxide gels wherein evaluated contain calcium in their composition. It is assumed that the presence of calcium is as the precursor of hydroxyapatite [32], and consequently, lower hydrogen peroxide can reach the pulp chamber when products with calcium phosphate are applied [18]. The pH of bleaching gels becomes an important factor when correlated with dental permeability, since most bleaching gels are acidic in order to stabilize and improve product life, they generate higher permeability [23, 18]. According to other studies [33, 34] either the $\mathrm{pH}$ of the bleaching gels used in this study are considered neutral, or what may have caused the lowest hydrogen concentration in hydrogen compared to the most commercially available acids $[23,35]$.

Therefore, we can conclude from this in vitro study that the at-home products herein tested and used by the time recommended by the manufacturer led to similar hydrogen 
peroxide concentration in the pulp chamber of bleached teeth.

\section{CONCLUSION}

Bleaching agents used in office bleaching presented higher amounts of hydrogen peroxide in the pulp. While in home systems, the amount of HP that reaches the pulp chamber is not proportional to the concentration of whitening gels, but depends on the application time recommended by the manufacturers.

\section{Acknowledgments}

This study was performed by Sibelli Olivieri Parreiras as partial fulfillment of his Phd degree at the State University of Ponta Grossa (UEPG), Ponta Grossa, PR, Brazil. The authors would like to thank FGM Dental Products for the generous donation of the bleaching products employed in this study.

This study was partially supported by the National Council for Scientific and Technological Development (CNPq) under grants 305588/2014-1 and 304105/2013-9 as well as Araucária Foundation.

\section{REFERENCES}

1. SilvaFBD, Chisini LA, Demarco FF, Horta BL, Correa MB. Desire for tooth bleaching and treatment performed in Brazilian adults: findings from a birth cohort. Braz Oral Res. 2018;32:e12.

2. Joiner A. Review of the effects of peroxide on enamel and dentine properties. $\mathrm{J}$ Dent. 2007;35(12): 889-896.

3. Mokhlis GR, Matis BA, Cochran MA, Eckert GJ. A clinical evaluation of carbamide peroxide and hydrogen peroxide whitening agents during daytime use. J AmDent Assoc. 2000; 131(9): 1269-1277.

4. Haywood VB. Treating sensitivity during tooth whitening. Compend Contin Educ Dent. 2005; 26 (9Suppl3): 11-20.

5. American Dental Association: Tooth whitening/bleaching: treatment considerations for dentists and their patients ADA Council on Scientific Affairs Chicago;2009.

6. Boushell LW, Ritter AV, Garland GE, et al. Nightguard vital bleaching: side effects and patient satisfaction 10 to 17 years post-treatment. i. 2012;24 (3): 211-219. doi: 10.1111/j.1708-8240.2011.00479.x

7. Tay LY, Kose C, Herrera DR, Reis A, Loguercio AD. Long-term efficacy of in-office and at-home bleaching: a 2-year double-blind randomized clinical trial. Am J Dent. 2012; 25 (4): 199-204.

8. Rezende M, Loguercio AD, KossatzS, Reis A. Predictive factors on the efficacy and risk/intensity of tooth sensitivity of dental bleaching: A multi regression and logistic analysis. J Dent. 2016; 45: 1-6. doi: 10.1016/j.jdent.2015.11.003.

9. Cardenas AFM, Maran BM, Araújo LCR, de Siqueira FSF, Wambier LM, Gonzaga CC, Loguercio AD, Reis A. Are combined bleaching techniques better than their sole application? A systematic review and meta-analysis. Clin Oral Investig. 2019;23(10):3673-3689. doi: 10.1007/s00784-019-03042-4.

10. Basting RT, Amaral FL, Franca FM, Florio FM. Clinical comparative study of the effectiveness of and tooth sensitivity to $10 \%$ and $20 \%$ carbamide peroxide home-use and $35 \%$ and $38 \%$ hydrogen peroxide in-office bleaching materials containing desensitizing agents. Oper Dent. 2012;37 (5):464-473. doi:10.2341/11-337-C.

11. Kose C, Calixto AL, Bauer JR, Reis A, Loguercio AD. Comparison of the Effects of In-office Bleaching Times on Whitening and Tooth Sensitivity: A Single Blind, Randomized Clinical Trial. Oper Dent. 2016 Mar-Apr;41(2):138-45.

12. Vaez SC, Correia A, Santana TR, Santana M,Peixoto AC, Leal PC, Faria-E-Silva AL. Is a Single Preliminary Session of In-office Bleaching Beneficial for the Effectiveness of At-home Tooth Bleaching? A Randomized Controlled Clinical Trial. Oper Dent. 2019 Jul/Aug;44(4):E180-E189.

13. Cintra LT, Benetti F, Ferreira LL, Rahal V, Ervolino E, Jacinto Rde C, Gomes Filho JE, Briso AL. Evaluation of an experimental rat model for comparative studies of bleaching agents. J Appl Oral Sci. 2016 Apr;24(2):171-80.

14. Soares DG, Basso FG, Hebling J, de Souza Costa CA. Concentrations of and application protocols for hydrogen peroxide bleaching gels: effects on pulp cell viability and whitening efficacy. J Dent. 2014 Feb;42(2):185-98.

15. Cooper JS, Bokmeyer TJ, Bowles WH. Penetration of the pulp chamber by carbamide peroxide bleaching agents. J Endod. 1992; 18(7):315-317.

16. Bowles WH,UgwuneriZ. Pulp chamber penetration by hydrogen peroxide following vital bleaching procedures. J Endod. 1987; 13(8):375-377.

17. Mendham J,Afonso JC. Vogel Quantitative chemical analysis. 1st ed. Livros Tecnicos e Científicos Editora S.A., 2002

18. Mena-Serrano AP,Parreiras SO, do Nascimento EM, et al. Effects of the concentration and composition of in-office bleaching gels on hydrogen peroxide penetration into the pulp chamber. Oper Dent. 2015; 40 (2): 76-82 doi: 10.2341/13-352-L

19. Marson FC, Goncalves RS, Silva CO, et al. Penetration of hydrogen peroxide and degradation rate of different bleaching products. Oper Dent. 2015; 40 (1):72-79. doi: 10.2341/13-270-L.

20. Gokay 0, Mujdeci A, Algin E. In vitro peroxide penetration into the pulp chamber from newer bleaching products. IntEndod J.2005;38 (8):516-520.

21. Hegedus C, Bistey T,Flora-Nagy E, Keszthelyi G, Jenei A. An atomic force microscopy study on the effect of bleaching agents on enamel surface. JDent. 1999; 27 (7):509-515.

22. Briso AL, Goncalves RS, Costa FB, Gallinari MO, Cintra LT, Santos PH. Demineralization and hydrogen peroxide penetration in teeth with incipient lesions. Braz Dent J.2015; 26 (2): 135-40. doi: 10.1590/0103-6440201300225.

23. AcunãED, Parreiras SO, Favoreto MW, etal. In-Office bleaching with a commercial $40 \%$ hydrogen peroxide fel modified to have different pHs: Color change, surface morphology, and penetration of hydrogen peroxide into theu pulp chamber . JEsthet Restor Dent. 2019;31(1):1-6. doi:10.1007/s00784-0141285-3.

24. de Geus JL, Wambier LM, Boing TF, Loguercio AD, Reis A. At-home bleaching with $10 \%$ vs more concentrated carbamide peroxide gels: A systematic review and meta-analysis. Oper Dent. 2018; 43 (4): 210-222.

25. Meireles SS, Heckmann SS, LeidaFL, dos Santos Ida S, Della Bona A, Demarco FF. Efficacy and safety of $10 \%$ and $16 \%$ carbamide peroxide tooth-whitening gels: a randomized clinical trial. Oper Dent. 2008;33(6):606-612.

26. Braun A, Jepsen S, Krause F. Spectrophotometric and visual evaluation of vital tooth bleaching employing different carbamide peroxide concentrations. Dent Mater.2007;23(2): 165-169.

27. Krause F, Jepsen S, Braun A. Subjective intensities of pain and contentment with treatment outcomes during tray bleaching of vital teeth employing 
different carbamide peroxide concentrations. Quintessence Int 2008;39 (3):203-209. doi:10.2341/07-150.

28. Delgado E, Hernandez-CottPL, StewartB, Collins M, De Vizio W. Toothwhitening efficacy of custom tray-delivered $9 \%$ hydrogen peroxide and $20 \%$ carbamide peroxide during daytime use: a 14-day clinical trial. PRHealth Sci J. 2007; 26(4):367-372

29. Ziebolz D, Helms K, Hannig C, Attin T. Efficacy and oral side effects of two highly concentrated tray-based bleaching systems. Clin Oral Investig. 2007;11(3): 267-275.

30. Alonso de la Pena V, Lopez Raton M. Randomized clinical trial on the efficacy and safety of four professional at-home tooth whitening gels. Oper Dent. 2014; 39(2): 136-143.

31. Featherstone JD. The continuum of dental caries-evidence for a dynamic disease process. J Dent Res. 2004; 83 Spec No C:C 39-42.
32 Kensche A, Pötschke S, Hannig C, Richter G, Hoth-Hannig W, Hannig M. Influence of Calcium Phosphate and Apatite Containing Products on Enamel Erosion. ScientificWorldJournal. 2016; ID7959273. doi: 10.2341/12-402-C.

33. Balladares L, Alegría-Acevedo LF, Montenegro-Arana A, Arana-Gordillo LA, Pulido C, Salazar-Gracez MT, Reis A, Loguercio AD. Effects of pH and Application Technique of In-office Bleaching Gels on Hydrogen Peroxide Penetration into the Pulp Chamber. Oper Dent. 2019;44 (6):659-667.

34. Cavalli V, Silva BGD, Berger SB, Marson FC, Tabchoury CPM, Giannini M. Decomposition Rate, $\mathrm{pH}$, and Enamel Color Alteration of At-Home and In-Office Bleaching Agents. BrazDent J.2019;30 (4):385-396.

35. Loguercio AD, ServatF, Stanislawczuk R, Mena-Serrano A, Rezende M, Prieto MV,Cereño V, Rojas MF,Ortega K, FernandezE, Reis A. Effect of acidity of inoffice bleaching gels on tooth sensitivity and whitening: a two-center doubleblind randomized clinical trial. Clin Oral Investig. 2017;21(9): 2811-2818.

\section{Alessandra Reis}

(Corresponding address)

State University of Ponta Grossa, Dental Post-Graduate Program, Rua Carlos

Cavalcanti, 4748, Bloco M - Uvaranas, Ponta Grossa, Paraná - Brazil. 